\title{
ALPHA FETOPROTEIN; \\ USEFUL AS SCREENING TEST FOR HEPATOCELLULAR CARCINOMA DUE TO CHRONIC HEPATITIS C
}

\footnotetext{
1. MBBS

RMO/PGR Department of Medicine Aziz Bhatti Shaheed Teaching Hospital, Gujrat.

2. MBBS,FCPS Medicine

Assistant Professor of Medicine Nawaz Sharif Medical College, University of Gujrat.

3. MBBS

RMO/PGR Department of Medicine, Aziz Bhatti Shaheed Teaching Hospital, Gujrat.
}

Correspondence Address: Dr. Syed Muhammad Ali Shah RMO/PGR Department of Medicine Aziz Bhatti Shaheed Teaching Hospital, Gujrat.

syedmuhammadalishah5@gmail.com

Article received on:

24/10/2016

Accepted for publication:

$15 / 03 / 2017$

Received after proof reading: 06/05/2017

\section{Dr. Syed Muhammad Ali Shah', Dr. Zamir Butt², Dr. Muhammad Waqas ${ }^{3}$}

ABSTRACT... BACKGROUND: Hepatocellular carcinoma (HCC) is a primary tumor of the liver, which develops in the setting of chronic liver disease, particularly in patients with chronic hepatitis $B$ and $\mathrm{C}$ in almost $80 \%$ patients. Although there are no specific screening tests for diagnosis of HCC but alpha-fetoprotein (AFP) and abdominal ultrasound are commonly used. AFP $>400 \mathrm{ng} / \mathrm{ml}$ is considered diagnostic for HCC. Objective: The objective of study was to validate the use of alphafetoprotein as screening test for HCC due to chronic HCV. Study Design: Observational cross-sectional. Period: March 2014 to August 2016. Setting: Aziz Bhatti Shaheed Teaching Hospital Gujrat. Materials and Methods: 134 patients aged >35 years having liver cirrhosis due to chronic HCV and diagnosed with HCC using biphasic CT scan were included and were followed for 1 year. Serum AFP was divided in 3 categories and a value $<20 \mathrm{ng} / \mathrm{ml}$ - normal, $20-399 \mathrm{ng} / \mathrm{ml}$ - elevated and $>400 \mathrm{ng} / \mathrm{ml}$ - diagnostic of HCC. Liver nodules size and site was noted and divided in 4 categories. Severity of liver disease was calculated using Child Pugh Score. Analysis was done using SPSS 20.0. Results: AFP is diagnostic ( $>400 \mathrm{ng} / \mathrm{ml}$ ) in only $29.9 \%$ of patients with sensitivity of $43.3 \%$ at cut off value of $400 \mathrm{ng} / \mathrm{ml}$ and is significantly associated with severity of liver disease. Conclusion: AFP cannot be used as screening test for HCC in patients with cirrhosis due to chronic HCV. Abdominal ultrasound should be used for early detection of HCC due to chronic hepatitis $\mathrm{C}$.

Key words: $\quad$ Alpha-fetoprotein, Hepatocellular Carcinoma, Hepatitis C.

Article Citation: Shah SMA, Butt Z, Waqas M. Alpha Fetaprotein; useful as screening test for hepatocellular carcinoma due to chronic hepatitis C. Professional Med $\mathrm{J}$ 2017;24(5):641-645. DOI: 10.17957/TPMJ/17.3690

\section{INTRODUCTION}

Hepatocellular carcinoma (HCC) is a primary tumor of the liver. It usually develop in the presence of chronic liver disease, particularly due to chronic hepatitis $B$ and $C$ infections. Almost 250,000 to one million deaths globally per annum occur due to HCC. ${ }^{1-4}$ In males it is the fifth most commonly diagnosed cancer globally, and is the second leading cause of deaths due to cancer $^{5}$ while in females it is the seventh most commonly diagnosed cancer and the sixth leading cause of cancer-related death. ${ }^{6} \mathrm{~A}$ number of risk factors for the development of HCC have been identified. The risk factors include the chronic hepatitis C virus infection, hepatitis B carrier state, hemochromatosis and cirrhosis of almost any cause. ${ }^{7}$ Chronic hepatitis B and C virus infection account for almost 80 percent of cases. ${ }^{8}$ In patients with chronic HCV infections, HCC occurs in patients with advanced stages of liver cirrhosis. ${ }^{9}$

Although there are no specific screening tests for diagnosis of HCC but alpha fetoprotein (AFP) and abdominal ultrasound are most commonly used. The serum concentration of AFP is often elevated in patients with HCC. AFP $>400 \mathrm{ng} / \mathrm{ml}$ is considered diagnostic for HCC, although less than half of patients with HCC may generate that high levels of AFP. ${ }^{10}$

There are controversies in initial screening of patients at high risk of HCC. A study concluded that AFP levels may be normal in up to $40 \%$ of small HCCs and some tumors may not secrete AFP. ${ }^{11}$ In patients with acute or chronic viral hepatitis; elevated serum AFP may be seen in patients with chronic liver disease without HCC. ${ }^{12,13}$ One study suggests that biomarkers like AFP cannot be used as screening test alone 
and they should be complemented by ultrasound abdomen ${ }^{14}$ while other concluded that serum AFP elevation may be more suggestive of $\mathrm{HCC}$ in non-infected patients. ${ }^{15}$ According to Asia Pacific Association for study of Liver Diseases (APASL) guidelines, every patient with cirrhosis should have both alpha-fetoprotein AFP and ultrasound examination for screening of $\mathrm{HCC}^{16}$ however American Association for Study of Liver Diseases (AASLD) guidelines recommend only ultrasound examination for screening of HCC. ${ }^{17}$ One study in Pakistan suggest that AFP should be used with abdominal ultrasound for diagnosis of HCC. ${ }^{18}$

Pakistan is an under developing country and prevalence of HCV infection reported in various studies ranges from $2.2-14 \%{ }^{19}$ which translates into approximately 4.4 to 28 million people. Natural history of disease shows that $55-89 \%$ of acute HCV infection coverts to chronic HCV infection out of which 2-24\% will develop liver cirrhosis over 20 years. In patients with liver cirrhosis $1-4 \%$ will develop HCC every year. It translates into almost 0.0005 to 0.24 million patients who will develop $\mathrm{HCC}$ every year in Pakistan. Due to high disease burden it is necessary validate a screening test for HCC in patients with cirrhosis due to HCV so that effective and early management plan can be made. Thus the objective of study was to determine the sensitivity of alpha fetoprotein for $\mathrm{HCC}$ due to chronic HCV in Pakistani population.

\section{MATERIALS AND METHODS}

An observational cross-sectional study was conducted from March 2014 to August 2016 at Aziz Bhatti Shaheed Teaching Hospital Gujrat after approval of ethical committee. 134 patients aged more than 35 years who had liver cirrhosis due to chronic HCV and diagnosed with HCC using contrast enhanced biphasic CT scan having findings consistent with HCC were included after informed consent of patients using nonprobability consecutive sampling. All patients with other causes of HCC or having serious comorbidities of heart, lung, kidney, autoimmune liver disease, or the presence of other malignant tumors were excluded from study. All patients were followed for 1 year after enrollment in study and mortality was noted. Data was collected using a Performa. Age, gender, marital status, serum ALT levels, serum AFP levels, abdominal ultrasound findings, CT-scan findings and Child Pugh Score were noted.

Serum AFP was divided in 3 categories and a value $<20 \mathrm{ng} / \mathrm{ml}$ was considered normal, 20-399 $\mathrm{ng} / \mathrm{ml}$ was considered elevated and $>400 \mathrm{ng} / \mathrm{ml}$ was considered diagnostic of HCC. Abdominal ultrasound was done by consultant radiologist (Toshiba Nemio 3) and liver cirrhosis and presence of hepatic nodules along with liver span were noted. Patients having liver size $<10 \mathrm{~cm}$ in longest axis and moderated to markedly coarse echotexture of liver were considered to have cirrhosis. Liver nodules size and site was noted and divided in 4 categories i.e single liver nodule $<3 \mathrm{~cm}$, single liver nodule $>3 \mathrm{~cm}$, three liver nodules all of them $<3 \mathrm{~cm}$ and multiple liver nodules. Severity of liver disease was calculated using Child Pugh Score and score 5-6 was defined as Child Class A, 7-9 as Child Class B and $10-15$ as Child Class C. Contrast enhanced biphasic CT scan was done and was reported by consultant radiologist.

Data analysis was done using Statistical Package for the Social Sciences (SPSS) version 20.0. Results are expressed as mean \pm SD for continuous variables such as age, liver span, ALT levels, Serum AFP levels and number (percentage) for categorical data such as gender, cirrhosis, ultrasound findings and Child Pugh Score. Chi Square test was applied to determine the association between AFP with severity of liver disease and AFP with tumor size and location and $p$-value $<0.05$ was considered significant.

\section{RESULTS}

Out of 134 patients 37 (27.6\%) were female and 97 (72.4\%) were male with male to female ratio of almost 3:1. The mean age was $58.73 \pm 9.605$ years. All patients were married and had liver cirrhosis. Mean liver span was $9.12 \pm 0.08 \mathrm{~cm}$. Mean serum ALT levels were $87.44 \pm 130.15 \mathrm{U} / \mathrm{L}$. The median AFP levels were $219.85 \mathrm{ng} / \mathrm{ml}$ with minimum of $0.80 \mathrm{ng} / \mathrm{ml}$ to maximum of 715510.20 $\mathrm{ng} / \mathrm{ml}$. 
$36(26.9 \%)$ patients had normal serum AFP levels (< $20 \mathrm{ng} / \mathrm{ml}), 58$ (43.3\%) had elevated serum AFP levels (20-399ng/ml) and $40(29.9 \%)$ patients had diagnostic serum AFP levels (> $400 \mathrm{ng} / \mathrm{ml}$ ).

89 (66.4\%) patients had nodules in right lobe of liver only, $19(14.2 \%)$ had nodules in left lobe only and 26 (19.4\%) had nodules in both right and left lobe of liver.

Single liver nodule $<3 \mathrm{~cm}$ was present in 17 (12.7\%) patients, single liver nodule $>3 \mathrm{~cm}$ was present in 55 (41\%) patients, 3 liver nodules all $<3 \mathrm{~cm}$ were present in $9(6.7 \%)$ patients while multiple liver nodules were present in 53 (39.6\%) patients.

25 (18.3\%) patients were Child Class A, 47 (35.1\%) were Child Class B and 62 (46.3\%) were Child Class $\mathrm{C}$. The mortality associated with HCC at 1 year was $55.22 \%$ (74) with mean duration of $2.91 \pm 2.40$ months after diagnosis of HCC. Patients characteristics are described in Table-l.

\begin{tabular}{|c|c|}
\hline \multicolumn{2}{|c|}{ Patients Characteristics } \\
\hline $\begin{array}{l}\text { No. of Patients and } \\
\text { Gender }\end{array}$ & $\begin{array}{l}\text { Total } 134 \\
\text { - } \quad \text { Female } 37(27.6 \%) \\
\text { - } \quad \text { Male } 97(72.4 \%)\end{array}$ \\
\hline Mean Age & $58.73 \pm 9.605$ years \\
\hline Mean Liver Span & $9.12 \pm 0.08 \mathrm{~cm}$ \\
\hline Mean ALT Levels & $87.44 \pm 130.15 \mathrm{U} / \mathrm{L}$ \\
\hline $\begin{array}{l}\text { Median AFP Levels } \\
\text { - Normal }<20 \mathrm{ng} / \mathrm{ml} \\
\text { - Elevated } 20-399 \mathrm{ng} / \mathrm{ml} \\
\text { - Diagnostic } \geq 400 \mathrm{ng} / \mathrm{ml}\end{array}$ & $\begin{array}{l}219.85 \mathrm{ng} / \mathrm{ml}, \text { Min. } \\
0.86 \mathrm{ng} / \mathrm{ml}, \mathrm{Max} . \\
715510.20 \mathrm{ng} / \mathrm{ml} \\
36(26.9 \%) \text { patients } \\
58(43.3 \%) \text { patients } \\
40(29.9 \%) \text { patients }\end{array}$ \\
\hline $\begin{array}{l}\text { Ultrasound Findings } \\
\text { - Location of Nodules } \\
\text { o Right Lobe } \\
\text { o Left Lobe } \\
\text { o Both right and left lobe } \\
\text { - Size of Nodules } \\
\text { o } \text { Single Nodule }<3 \mathrm{~cm} \\
\text { o } \quad \text { Single Nodule }>3 \mathrm{~cm} \\
\text { o } 3 \text { nodules all }<3 \mathrm{~cm} \\
\text { o } \text { Multiple nodules }\end{array}$ & $\begin{array}{l}89(66.4 \%) \text { patients } \\
19(14.2 \%) \text { patients } \\
26(19.4 \%) \text { patients } \\
17(12.7 \%) \text { of patients } \\
55(41 \%) \text { of patients } \\
9(6.7 \%) \text { of patients } \\
53(39.6 \%) \text { of patients }\end{array}$ \\
\hline $\begin{array}{l}\text { Child Pugh Score } \\
\text { - Child Class A } \\
\text { - Child Class B } \\
\text { - Child Class C }\end{array}$ & $\begin{array}{l}25(18.3 \%) \text { of patients } \\
47(35.1 \%) \text { of patients } \\
62(46.3 \%) \text { of patients }\end{array}$ \\
\hline
\end{tabular}

Table-I. Patients Characteristics
In 94 (70.1\%) of patients serum AFP levels were not diagnostic rather elevated or normal and were diagnostic only in 40 (29.9\%) of patients. There was a significant association noted between AFP levels and severity of liver disease (Child Pugh Score) $(p=0.019)$ but no significant association with tumor size and location was noted. The sensitivity of AFP was noted in diagnosing HCC at $20 \mathrm{ng} / \mathrm{ml}, 100 \mathrm{ng} / \mathrm{ml}, 200 \mathrm{ng} / \mathrm{ml}, 300 \mathrm{ng} / \mathrm{ml}$ and $400 \mathrm{ng} / \mathrm{ml}$ and was $73.1 \%, 55.2 \%, 50.7 \%, 45.5 \%$ and $43.3 \%$ respectively. (Table-II)

\begin{tabular}{|l|c|}
\hline Cut-off Value of AFP & Sensitivity \\
\hline $20 \mathrm{ng} / \mathrm{ml}$ & $73.1 \%$ \\
\hline $100 \mathrm{ng} / \mathrm{ml}$ & $55.2 \%$ \\
\hline $200 \mathrm{ng} / \mathrm{ml}$ & $50.7 \%$ \\
\hline $300 \mathrm{ng} / \mathrm{ml}$ & $45.5 \%$ \\
\hline $400 \mathrm{ng} / \mathrm{ml}$ & $43.3 \%$ \\
\hline \multicolumn{2}{|c|}{ Table-Il. Sensitivity of AFP at different cut-off } \\
values
\end{tabular}

\section{DISCUSSION}

AFP is used in initial screening of HCC along with ultrasound. ${ }^{16}$ In this study we tried to validate AFP as initial screening tool for HCC due to chronic hepatitis $\mathrm{C}$ and found out that AFP is diagnostic (> $400 \mathrm{ng} / \mathrm{ml}$ ) in only $29.9 \%$ of patients with sensitivity of $43.3 \%$ at cut off value of $400 \mathrm{ng} / \mathrm{ml}$ and is significantly associated with severity of liver disease.

High incidence of HCC in males in our study is supported by various international studies but with a comparatively less percentage. Haque IU et al. in their study ${ }^{20}$ showed the $72.33 \%$ of male patients had HCC which is almost equal to our study $(72.4 \%)$ despite different sample size. The patients included in their study had HCC due to both HBV and HCV compared to only HCV in this study. The study also suggested that normal AFP levels should always be supported by sensitive imaging technique before excluding HCC. They also concluded that AFP levels are co-related to tumor size which is contrary to our results.

In another local study ${ }^{18}$ the sensitivity of AFP was found to be $72.2 \%$ (Vs $73.1 \%$ ) at cutoff value of $20 \mathrm{ng} / \mathrm{ml}, 50.2 \%$ (Vs 55.2\%) at $100 \mathrm{ng} / \mathrm{ml}, 45.6 \%$ (Vs $50.7 \%$ ) at $200 \mathrm{ng} / \mathrm{ml}$ and $42.7 \%$ (Vs 43.3\%) at 
$400 \mathrm{ng} / \mathrm{ml}$ which is comparable to our study. This limitation of AFP is most likely due to the fact that a number of small tumors may not secrete AFP resulting in normal levels despite the presence of HCC. ${ }^{21}$

A systemic review of test characteristics of a-Fetoprotein for detecting HCC in patients with hepatitis $\mathrm{C}^{22}$ indicated sensitivity of AFP levels higher than $20 \mu \mathrm{g} / \mathrm{L}$ ranged from $41 \%$ to $65 \%$ compared to $73.1 \%$ in our study while sensitivity at levels higher than $200 \mu \mathrm{g} / \mathrm{L}$ was very low $(20 \%$ to $45 \%$ ) compared to $50.7 \%$. This difference may be due to small sample size in our study.

In our study $80.6 \%$ patients had a single nodule $>3 \mathrm{~cm}$ or multiple nodules on abdominal ultrasound which shows that most of our patients are detected late and are left with very limited or no treatment options. ${ }^{23}$ This is also indicated by early and high mortality in our study.

Our results indicate that AFP cannot be used in the initial screening of HCC due to chronic HCV due to its low sensitivity at diagnostic values. There may be elevation of AFP in patients with chronic $\mathrm{HCV}$ infection and may be normal in patients with HCC. ${ }^{11,12,13}$ The findings are consistent with American Association for Study of Liver Diseases (AASLD) guidelines which recommend only abdominal ultrasound for screening. ${ }^{17}$ but against the Asia Pacific Association for study of Liver Diseases (APASL) guideline ${ }^{16}$ which recommend both AFP levels and abdominal ultrasound.

We recommend only abdominal ultrasound for initial screening of HCC in patients with cirrhosis due to chronic HCV. Ultrasound has $78-90 \%$ sensitivity and $93 \%$ specific for detection of $\mathrm{HCC}^{24}$ AFP levels are only able to provide additional detection in $6-8 \%$ of cases not previously identified by ultrasound. ${ }^{24}$ AFP cannot be used alone as screening test due to its low sensitivity at diagnostic value and raised AFP in patients with cirrhosis without HCC. ${ }^{11}$

\section{CONCLUSION}

AFP cannot be used as screening test for HCC in patients with cirrhosis due to chronic HCV. Abdominal ultrasound should be used for early detection of HCC due to chronic hepatitis C.

Copyright(C) 15 Mar, 2017.

\section{REFERENCES}

1. Munoz N, Bosch X. Epidemiology of hepatocellular carcinoma. In: Neoplasms of the Liver, Okuda K, Ishak KG (Eds), Springer, Tokyo 1989. p.3.

2. Muir C, Waterhouse J, Mack T, et al. Cancer incidence in five continents. Vol. 5 (IARC publications, No. 88), International Agency for Research on Cancer, Lyon, 1987.

3. Bosch FX, Munoz N. Hepatocellular carcinoma in the world: Epidemiologic questions. In: Etiology, Pathology and Treatment of Hepatocellular Carcinoma in America. Advances in Applied Technology Series, Tabor E, DiBisceglie AM, Purcell RH (Eds), Gulf, Houston 1991. p.35.

4. Okuda K. Epidemiology of primary liver cancer. In: Primary Liver Cancer in Japan, Tobe T (Ed), SpringerVerlag, Tokyo 1992. p.3.

5. Jemal A, Bray F, Center MM, et al. Global cancer statistics. CA Cancer J Clin 2011; 61:69.

6. Altekruse SF, McGlynn KA, Reichman ME. Hepatocellular carcinoma incidence, mortality, and survival trends in the United States from 1975 to 2005. J Clin Oncol 2009; 27:1485.

7. Davila JA, Morgan RO, Shaib Y, et al. Hepatitis $C$ infection and the increasing incidence of hepatocellular carcinoma: a population-based study. Gastroenterology 2004; 127:1372.

8. Perz JF, Armstrong GL, Farrington LA, et al. The contributions of hepatitis $B$ virus and hepatitis C virus infections to cirrhosis and primary liver cancer worldwide. J Hepatol 2006; 45:529.

9. Lok AS, Seeff LB, Morgan TR, et al. Incidence of hepatocellular carcinoma and associated risk factors in hepatitis $\mathrm{C}$-related advanced liver disease. Gastroenterology 2009; 136:138.

10. Colombo M. Screening for cancer in viral hepatitis. Clin Liver Dis.2001; 5:109-22.

11. Chen DS, Sung JL, Sheu JC, et al. Serum alphafetoprotein in the early stage of human hepatocellular carcinoma. Gastroenterology 1984; 86:1404.

12. Collier J, Sherman M. Screening for hepatocellular carcinoma. Hepatology 1998; 27:273. 
13. Sterling RK, Wright EC, Morgan TR, et al. Frequency of elevated hepatocellular carcinoma (HCC) biomarkers in patients with advanced hepatitis $\mathrm{C}$. Am J Gastroenterol 2012; 107:64.

14. Lok AS, Sterling RK, Everhart JE, Wright EC, Hoefs JC, Di Bisceglie AM, et al.; HALT-C Trial Group. Des-gammacarboxy prothrombin and alpha-fetoprotein as biomarkers for the early detection of hepatocellular carcinoma. Gastroenterology 2010; 138:493-502.

15. Trevisani, Franco et al. Serum a-fetoprotein for diagnosis of hepatocellular carcinoma in patients with chronic liver disease: influence of $\mathrm{HBsAg}$ and anti-HCV status. J Hepatol. $2001 \mathrm{Apr}$; 34(4):570-5.

16. Omata M, Laurentius A, Lesmana, Tateishi R, Chen P, Lin $\mathrm{S}$, et al. Asian Pacific Association for the study of the liver consensus recommendations on hepatocellular carcinoma. Hepatol Int 2010; 4:439-74.

17. Bruix J, Sherman M. Management of hepatocellular carcinoma: an update. Hepatology 2011; 53:1020-55.

18. Sarwar S, Khan AA, Tarique S. Validity of Alpha Fetoprotein for Diagnosis of Hepatocellular Carcinoma in Cirrhosis. J Coll Physicians Surg Pak. 2014, Vol. 24 (1): 18-22.
19. Sy $T$, Jamal MM. Epidemiology of hepatitis $\mathbf{C}$ virus (HCV) infection. Int J Med Sci 2006; 3:41-6.

20. Haque IU, Zafar S, Iqbal W, Hassan G, Farooq M, Nasir $B$ et al. Does Value of Alpha Fetoprotein Matter in HCC? Pak J Med Health Sci 2015; 9(1):305-7.

21. Gebo KA, Chander G, Jenckes MW, Ghanem KG, Herlong HF, Torbenson MS, et al. Screening tests for hepatocellular carcinoma in patients with chronic hepatitis C: a systematic review. Hepatology 2002; 36:S84-S92.

22. Gupta S, Bent S, Kohlwes J. Test Characteristics of a-Fetoprotein for Detecting Hepatocellular Carcinoma in Patients with Hepatitis C: A Systematic Review and Critical Analysis. Ann Intern Med. 2003; 139(1):46-50.

23. Jiang $\mathrm{J}$, Wu $\mathrm{C}$, Shen $\mathrm{Y}$, et.al. Clinical application of determining serum AFP-IgM complexes for diagnosis of small hepatocellular carcinoma. Anticancer Res 2011, 31:687-691.

24. European Association for the Study of the Liver, European Organisation for Research and Treatment of Cancer. EASLEORTC clinical practice guidelines: management of hepatocellular carcinoma. J Hepatol 2012; 56:908-43.

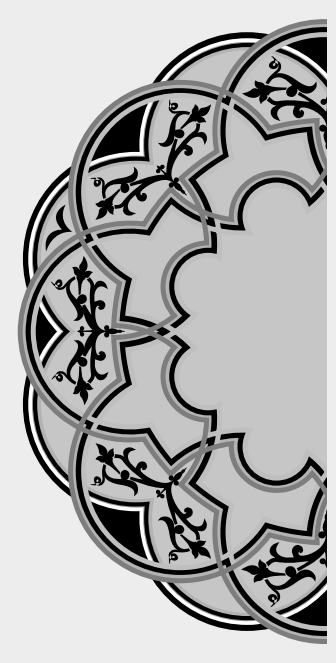

\author{
"if you want something \\ you're never had then \\ you've got to do something \\ you've never done."
}

Unknown

\title{
AUTHORSHIP AND CONTRIBUTION DECLARATION
}

\begin{tabular}{|c|l|l|l|}
\hline Sr. \# & \multicolumn{1}{|c|}{ Author-s Full Name } & \multicolumn{1}{|c|}{ Contribution to the paper } & Author=s Signature \\
\hline 1 & Dr. Syed M. Ali Shah & 1st Author & \\
\hline 2 & Dr. Zamir Butt & 2nd Author \\
\hline 3 & Dr. Muhammad Waqas & 3rd Author & \\
\hline
\end{tabular}

